\title{
Description of the female of Spodochlamys marahuaca Jameson \& Ratcliffe, 2011 (Melolonthidae, Rutelinae, Anatistini) and additional records for the Brazilian species of the genus
}

\author{
Matheus BENTO ${ }^{1 *}$, , Paschoal Coelho GROSSI ${ }^{2}$ \\ Instituto Nacional de Pesquisas da Amazônia (INPA), Coordenação de Biodiversidade. Av. André Araújo 2936, CP 478, 6901 1-970 Manaus, Amazonas, Brasil \\ 2 Universidade Federal Rural de Pernambuco (UFRPE), Programa de Pós-Graduação em Entomologia Agrícola, Laboratório de Taxonomia de Insetos, Rua Manoel \\ Medeiros, s/n, Dois Irmãos, 52171-900 Recife, Pernambuco, Brasil \\ * Corresponding author: mabento2008@gmail.com; (D) https://orcid.org/0000-0001-9846-9728
}

\section{ABSTRACT}

The previously unknown female of Spodochlamys marahuaca Jameson \& Ratcliffe, 2011 is described and illustrated for the first time based on two specimens collected in the region of the Juruá River, Amazonas state, Brazil. The specimens constitute a new record for Brazil. The identification key for species of Spodochlamys is updated, as well as the geographic distribution of the other two Brazilian species, S. caesarea Burmeister and S. iheringi Ohaus.

KEYWORDS: Amazon, Neotropical region, geographic distribution, taxonomy, Scarabaeoidea

\section{Descrição da fêmea de Spodochlamys marahuaca Jameson \& Ratcliffe, 2011 (Melolonthidae, Rutelinae, Anatistini) e registros adicionais para as espécies brasileiras do gênero}

\section{RESUMO}

A fêmea previamente desconhecida de Spodochlamys marahuaca Jameson \& Ratcliffe, 2011 é descrita e ilustrada pela primeira vez com base em dois espécimes coletados na região do Rio Juruá, Amazonas, Brasil. Os espécimes constituem um novo registro para o país. A chave de identificação para as espécies de Spodochlamys é atualizada, bem como a distribuição geográfica das duas outras espécies brasileiras, $S$. caesarea Burmeister e $S$. iheringi Ohaus.

PALAVRAS-CHAVE: Amazônia, região Neotropical, distribuição geográfica, taxonomia, Scarabaeoidea

The ruteline beetles belonging to the Neotropical tribe Anatistini (Rutelinae) comprise 21 species distributed in four genera: Anatista Brême, 1844, Chalcochlamys Ohaus, 1905, Spinochlamys Machatschke, 1970 and Spodochlamys Burmeister, 1855, occuring from Honduras to central and western Brazil (Jameson and Ratcliffe 2011). They are characterized by the presence of a labrum vertically produced with respect to the clypeus and somewhat fused to the clypeus, each labrum and mentum lacking a medioapical projection, maxillary teeth directed approximately at a 90 degree angle with respect to the longitudinal axis of the maxillae, a mandible with a strongly developed molar lobe, and the protibia lacking spurs.

Spodochlamys is the most diverse genus of Anatistini, with about $80 \%$ of the species, and can be easily distinguished from the other genera by the clypeal apex broadly rounded, parabolic, or with a median tooth, the pronotum not vertically elevated anteriorly, the mesoventrite not produced beyond the base of the mesocoxae, and the length of the antennal club subequal to twice the length of the antenommeres 2-7 combined (Jameson and Ratcliffe 2011). From the 17 species known only two had been recorded in Brazil: $S$. caesarea Burmeister, 1855 in the states of Amazonas, Bahia, Goiás and Pará, and S. iheringi Ohaus, 1905 in Bahia, Goiás, Mato Grosso, Pará and Rondônia (Ohaus 1918; Jameson and Ratcliffe 2011; Ferreira et al. 2018).

Spodochlamys marahuaca Jameson \& Ratcliffe, 2011 is a species known only by the male holotype from Venezuela. Here we complement the characterization of the species by reporting and describing the previously unknown female of 
S. marahuaca from Brazil, providing means for the reliable identification of the species and extending the knowledge about its geographical distribution. We also update the identification key for Anatistini females and add new records of the other two Brazilian species, S. caesarea and S. iheringi.

The studied specimens are deposited in the Entomological Collection of Universidade Federal Rural de Pernambuco, in Recife, Pernambuco, Brazil (CERPE), the Invertebrate Collection of Instituto Nacional de Pesquisas da Amazônia (INPA), the Zoological Collection Prof. Paulo Bührnheim of Universidade Federal do Amazonas (CZPB), in Manaus, Amazonas, Brazil, and the Entomological Collection of Universidade Federal do Mato Grosso, Mato Grosso, Brazil (CEMT). The holotypes of $S$. marahuaca and S. neblina Jameson \& Ratcliffe, 2011 (University of Nebraska State Museum, UNSM) were analyzed from pictures (Figure 1). The identification was made based on the original descriptions of the species and the existing key (Jameson and Ratcliffe 2011). We followed Jameson and Ratcliffe (2011) for definition of morphological characters and measurements.

The crenulation of the pronotal and elytral margins was defined as (1) densely crenulated: fully crenulated margin, majority of crenulations separated from each other by a distance of less than $0.6 \mathrm{~mm}$; (2) moderately crenulated: fully crenulated margin, but with crenulations separated from each other by a distance greater than $0.6 \mathrm{~mm}$; and (3) sparsely crenulated: margin with only a few crenulations.

The geographic coordinates of the collection sites were obtained with Google Maps and the georeferenced points were plotted on the distribution maps derived from the websoftware Simplemappr (Shorthouse 2010).

Images were taken using a Nikon D90 with a $40 \mathrm{~mm}$ macro lens, using the software Helicon remote. Multifocus images were stacked with Combine ZP software. The final stacked photos were edited, and the plates were made in Adobe Photoshop ${ }^{\circledR}$.

Spodochlamys marahuaca Jameson \& Ratcliffe, 2011

Material examined: "BRASIL, Amazonas, Juruál Mineruazinho, 0334'85"S, 6659'15”W, 13-25.I.1996/ P. Buhrnheim; N. O. Aguiar et al. leg." // "Armadilha/ Pensylvania/ Luz negra BLB" ( $\$$, CERPE 000002; + CZPBCO000756, ơ CZPB-CO000755).

Description. Female (Figure 2). Length $30.0-30.5 \mathrm{~mm}$; width 11.0-13.3 mm. Coloration: Dorsal surface and legs matte black, opaque; ventral surface black with weak reddish reflections at middle. Head: Frons densely punctate; interocular width 4.1-4.3 times wider than transverse eye diameter. Frontoclypeal suture complete. Clypeus confluently punctate or rugopunctate, punctures large; anterior margin weakly parabolic in dorsal view, weakly reflexed in lateral view. Ocular canthus cariniform. Ventral clypeal face slightly wider at middle than on sides, apex concave. Labrum length greater than two times the length of ventral face of clypeus medially, vertically produced with respect to clypeal apex, weakly and obtusely angulated at apex. Mentum convex, lacking longitudinal furrow, subquadrate, apex notched medially. Labial palpi 3-segmented, subapical palpomere with

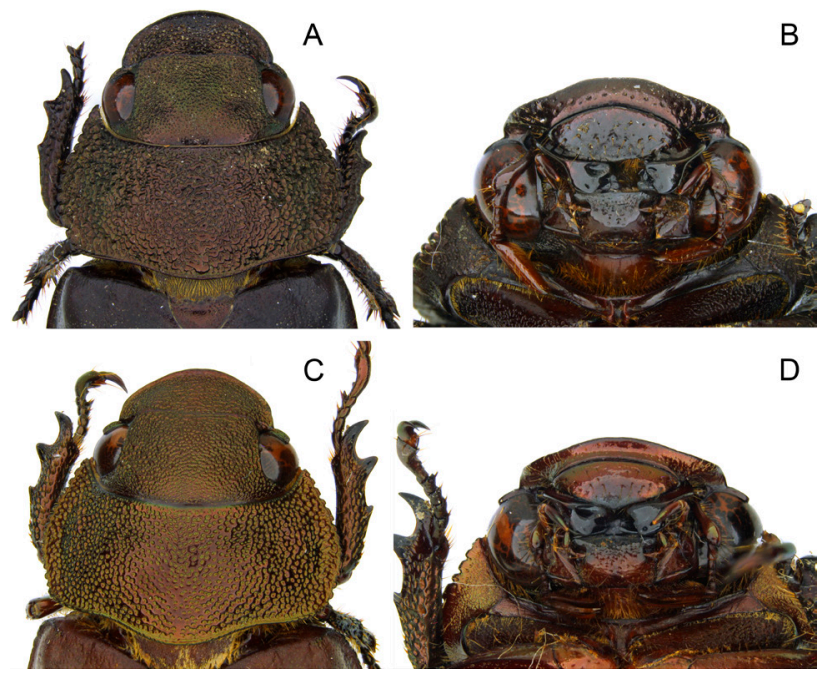

Figure 1. Male holotype of Spodochlamys marahuaca Jameson \& Ratcliffe: A. head and pronotum in dorsal view; B. head in ventral view. Male holotype of Spodochlamys neblina Jameson \& Ratcliffe; C. head and pronotum in dorsal view; D. head in ventral view. Credit: M. J. Paulsen. This figure is in color in the electronic version.
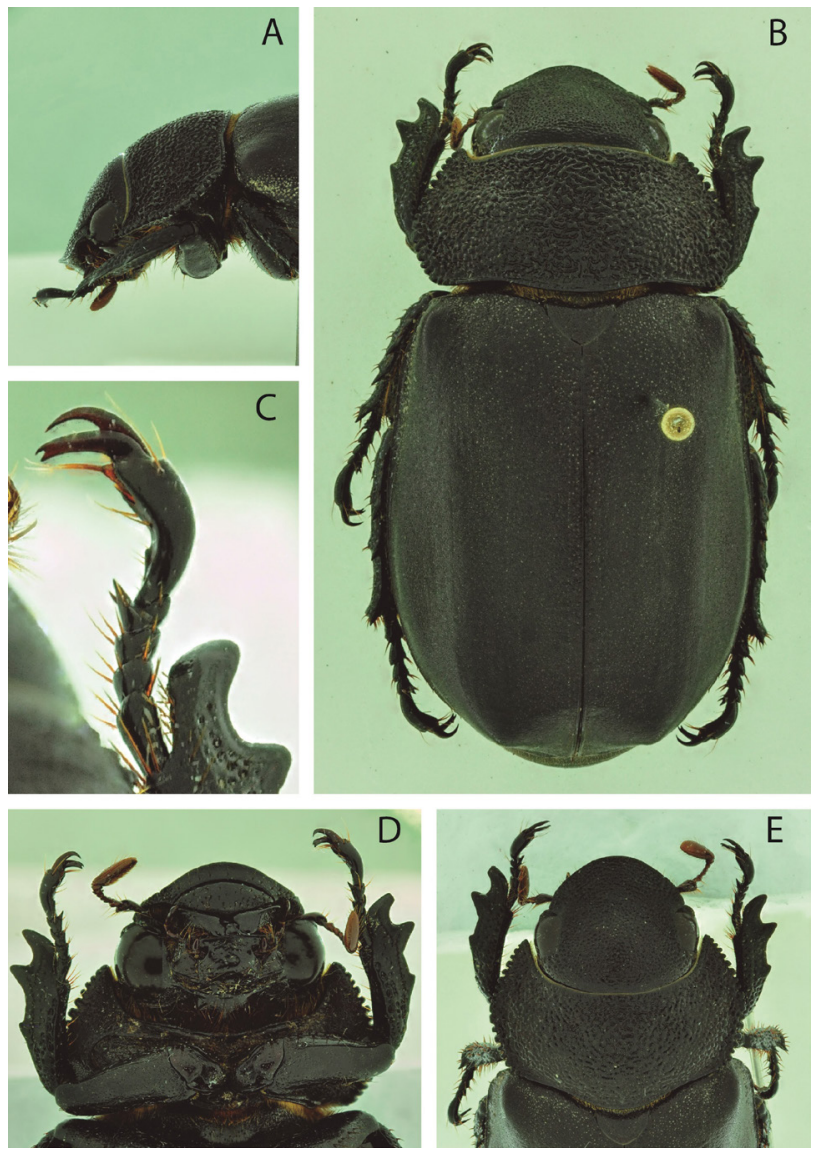

Figure 2. Spodochlamys marahuaca Jameson \& Ratcliffe, female CERPE 000002. A. head and prothorax in lateral view; B. dorsal habitus; C. protarsus, and protarsal claws; D. head, and prothorax in ventral view; E. head and pronotum in dorsal view. Credit: P. C. Grossi. This figure is in color in the electronic version. 
small dorsoapical projection. Antenna with club about 1.2 times longer than antenommeres 2-7 combined. Pronotum: surface coarsely rugopunctate; evenly convex in lateral view; anterior marginal bead absent medially; lateral margin densely crenulate; posterior margin weakly bisinuous, with complete bead. Scutellum: Surface densely punctate, wider than long, posterior angle rounded. Elytra: Surface densely and finely punctate; striae absent; sutural margin weakly rugose at base; lateral margin moderately crenulate. Elytral epipleuron gradually narrowed and incomplete. Apical umbone with a rounded, moderately developed tubercle. Sutural stria well defined at apex. Pygidium: Disc evenly rounded in lateral view, not protuberant; surface finely and confluently punctate at base and lateral margins, punctures minute; disc densely punctate. Venter: Mesoventral apex not produced, without process. Legs: Inner protarsal claw and outer claws on meso- and metatarsi narrowly split; protarsomere 5 with weakly developed ventromedial ridge. Protibia without ventral subapical projection, with outer margin tridentate, proximal tooth reduced, inner margin more or less straight; protibial spur absent. Profemur without a ventromedial projection. Meso- and metatibia with apex expanded, outer margin with three acute spine-like teeth; meso- and metatibial spurs simple and not hooked; metatibia with one ventroexternal, transversal carina. Metatrochanter with apex not produced beyond posterior margin of metafemur.

Diagnosis. The females of $S$. marahuaca can be distinguished from males by (opposing to males): anterior margin of the clypeus weakly parabolic in dorsal view (broadly rounded in dorsal view); pronotum with lateral margins rounded anteriorly (almost straight anteriorly); broader protibial teeth (narrower); inner protarsal claw narrowly split (inner claw simple); and protarsomere 5 with weakly developed, ventromedial ridge (moderately developed). They are also distinguished from the females of other species of the genus by the following character combination: 1) dorsal coloration matte black, opaque, without waxy bloom and greenish or cupreous reflections on pronotum; 2) anterior bead of pronotum incomplete; 3) surface of pronotum coarsely rugose; 4) clypeus in frontal view noticeably convex medially; and 5) outer metatarsal claw narrowly split.

Discussion. This is a distinctive species of Spodochlamys, possessing a matte black, opaque dorsal surface, and surface of the pronotum coarsely rugopunctate. Spodochlamys marahuaca is similar to $S$. neblina (only the male known), but differs from it by the following combination of characters (opposing to $S$. neblina): 1) elytra with apical umbone rounded (apical umbone more or less a pointed tubercle);2) metatibial apical spur simple (weakly hooked); and 3) apex of metatibia with a spine-like tooth (lacking tooth).

Jameson and Ratcliffe (2011) were correct when they hypothesized that the hitherto unknown female had dark, opaque elytra. However, it is not restricted to the isolated locality of the type, as they previously believed. Here, we record this species for the first time in Brazil (new country record).

Three species of the genus are now known to occur in Brazil, and we present additional new records for two of them: $S$. caesarea is here registered to Maranhão, Paraíba, Pernambuco, and Alagoas states, whereas S. iheringi is additionally registered to the states of Roraima, Amazonas, Maranhão, and Tocantins (Figure 3). Ferreira et al. (2018) erroneously mentioned the occurrence of $S$. caesarea in São Paulo state based on Ohaus (1918), but instead, this species was recorded from São Paulo de Olivença municipality in southeastern Amazonas state.

Material examined. Spodochlamys caesarea Burmeister. Amazonas: Presidente Figueiredo (, INPA); Maranhão: Reserva Biológica do Gurupi (o', CERPE); Paraiba: João Pessoa (ơ + , CERPE); Pernambuco: Recife ( $\$$, CERPE), Igarassu (ơ $q$, EPGC), Cabo de Santo Agostinho (CEMT), Camaragibe ( $9, \mathrm{CERPE})$; Alagoas: Ibateguara ( $\$, \mathrm{CERPE})$. Spodochlamys iheringi Ohaus. Amazonas: Coari (o' CZPB); Roraima: Yanomami (\%, INPA); Pará: Redenção, Reserva Pinkaiti (CEMT), Barcarena (20', 2, EPGC); Maranhão: Balsas, Serra do Penitente (20', EPGC), Carolina (ㅇ, CERPE); Rondônia: Jirau, Porto Velho (CEMT), Candeias do Jamari (o', CZPB), São Domingos, Parque Natural de Porto Velho (ơ', CERPE); Mato Grosso: Sinop (o', EPGC), Diamantino, Serra das Araras, Paranaíta, Porto Esperidião, Cotriguaçu, Comodoro, Chapada dos Guimarães, Itanhangá, Lucas do Rio Verde, Novo Mundo (CEMT, CERPE); Tocantins: Ponte Alta do Tocantins (CEMT); Distrito Federal: Planaltina (CEMT).

For the inclusion of the Spodochlamys marahuaca female, the female key of Jameson and Ratcliffe (2011) is modified as follows:

5. Ventral face of clypeus longer at middle than at sides .......11

5'. Ventral face of clypeus with apical and basal margins subparallel 6

6. Outer metatarsal claw widely split ............S. cupreola Bates

6'. Outer metatarsal claw narrowly split ..........................7

7. Elytra with waxy bloom ......................S. iheringi Ohaus

7’. Elytra without waxy bloom ......................................8

8. Pronotal apical bead lacking at middle ........................9

8'. Pronotal apical bead complete, at least at middle and laterally .......................................................... 10

9. Dorsal color light castaneous; head, pronotum, and scutellum with weak greenish reflections .........S. flavofemorata Ohaus 9'. Dorsal color black matte, opaque, without greenish reflections.....................S. marahuaca Jameson \& Ratcliffe

10. Mentum on apical third strongly declivous

..S. letiranti Jameson \& Ratcliffe

10'. Mentum on apical third not noticeably declivous, instead with triangular depression on disc ................S. soulai Curoe

11. Elytra with waxy bloom ...........S. caesarea Burmeister 11'. Elytra without waxy bloom. S. neitai Jameson \& Ratcliffe 


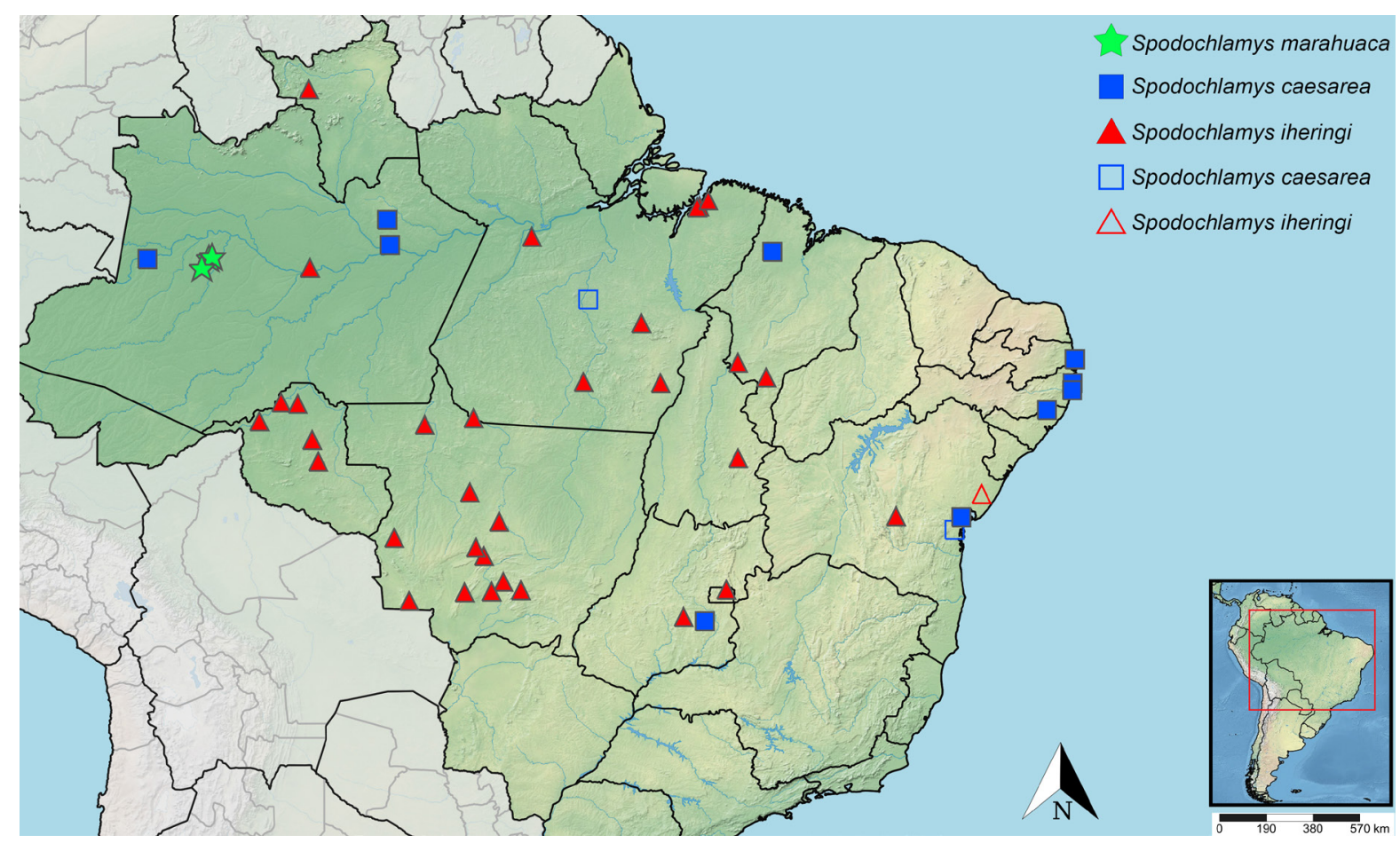

Figure 3. Distribution map of Brazilian Spodochlamys species (open symbols represent state records only). This figure is in color in the electronic version.

\section{ACKNOWLEDGMENTS}

We thank the curators of the collections, namely Fabio Siqueira Pitaluga de Godoi (CZPB), Fernando Zagury Vaz-de-Mello (CEMT) and Márcio de Oliveira (INPA), for providing the material included in this paper. M. J. Paulsen (UNSM) is thanked for sending images of the holotypes of S. marahuaca and S. neblina. We thank also the reviewers for their constructive remarks. MB thanks the Conselho Nacional de Desenvolvimento Científico e Tecnológico (CNPq) for the financial support (Process 132195/2017-8).

\section{REFERENCES}

Ferreira, A.S.; Almeida, L.M.; Bravo, F.; Grossi, P.C. 2018. A checklist of Rutelinae MacLeay, 1819 (Coleoptera: Melolonthidae) of Bahia, Brazil. Biota Neotropica, 18: 1-11.

Jameson, M.L.; Ratcliffe, B.C. 2011. The Neotropical scarab beetle tribe Anatistini (Coleoptera: Scarabaeidae: Rutelinae). Bulletin of the University of Nebraska State Museum, 26: 1-100.

Ohaus, F. 1918. Scarabaeidae: Euchirinae, Phaenomerinae, Rutelinae. Coleopterum Catalogus, Berlin 10: 9-217.

Shorthouse, D.P. 2010. SimpleMappr, an online tool to produce publication-quality point maps, (http://www.simplemappr.net). Accessed on 27 Jul 2018.

RECEIVED: $17 / 09 / 2018$

ACCEPTED: 20/05/2019

ASSOCIATE EDITOR: Ana Lúcia M. Tourinho 